\title{
Enhanced Production and Characterization of a Solvent Stable Amylase from Solvent Tolerant Bacillus tequilensis RG-01: Thermostable and Surfactant Resistant
}

\author{
Soni Tiwari, Neha Shukla, Pooja Mishra, and Rajeeva Gaur \\ Department of Microbiology, Centre of Excellence, Dr. Ram Manohar Lohia Avadh University, Faizabad, \\ Uttar Pradesh 224001, India \\ Correspondence should be addressed to Rajeeva Gaur; rajeevagaur@gmail.com
}

Received 2 July 2014; Accepted 19 September 2014; Published 27 October 2014

Academic Editor: Ramesh C. Kasana

Copyright (C) 2014 Soni Tiwari et al. This is an open access article distributed under the Creative Commons Attribution License, which permits unrestricted use, distribution, and reproduction in any medium, provided the original work is properly cited.

\begin{abstract}
Ten bacterial strains isolated from the soil samples in the presence of cyclohexane were screened for amylase production. Among them, culture RG-01 was adjudged as the best amylase producer and was identified as Bacillus tequilensis from MTCC, Chandigarh. The isolate showed maximum amylase production $(8100 \mathrm{U} / \mathrm{mL})$ in the presence of starch, peptone, and $\mathrm{Ca}^{2+}$ ions at $55^{\circ} \mathrm{C} \mathrm{pH} 7.0$ within $24 \mathrm{~h}$ of incubation. The enzyme was stable in the presence of $\mathrm{n}$-dodecane, isooctane, $\mathrm{n}$-decane, xylene, toluene, $\mathrm{n}$-hexane, n-butanol, and cyclohexane, respectively. The presence of benzene, methanol, and ethanol marginally reduced the amylase stability, respectively. The enzyme was showed it $100 \%$ activity at $55^{\circ} \mathrm{C}$ and $\mathrm{pH} 7.0$ with $119 \%$ and $127 \%$ stability at $55^{\circ} \mathrm{C}$ and $\mathrm{pH} 7.0$, respectively. The enzyme was also stable in the presence of SDS, Tween-40, Tween-60, and Tween-80 (1\%) and was found stimulatory effect, respectively. Only Triton-X-100 showed a moderate inhibitory effect (5\%) on amylase activity. This isolate (Bacillus tequilensis RG01) may be useful in several industrial applications owing to its thermotolerant and organic solvents and surfactants resistance characteristics.
\end{abstract}

\section{Introduction}

In modern times, the products of biological origin, particularly enzymes, are attracting the attention of researchers. Their role in several biological and commercial processes has been duly emphasized. Among all the enzymes, $\alpha$-amylases constitute a class of industrial enzyme having approximately $30 \%$ of the world enzyme production [1] and represent one of the three largest groups of industrial enzymes and account for approximately $25 \%$ of total enzymes sales [2] and are an important enzyme, particularly in the process of starch or glycogen hydrolysis.

The amylases can be derived from several sources such as plants, animals, and microbes. The major advantage of using microorganisms for production of amylases is in economical bulk production capacity and microbes are also easy to manipulate to obtain enzymes of desired characteristics $[3,4]$. Based on their mode of action, they are further classified into three categories: $\alpha$-amylases, $\beta$-amylases, and glucoamylases.
All amylases are glycoside hydrolyser and act on $\alpha-1,4$ glycosidic bonds [5]. Industrially, $\alpha$-amylase is used particularly in starch liquefaction, brewing, textile, pharmaceuticals, paper, detergents, drugs, toxic wastes removal, and oil drilling [6]. Since $\alpha$-amylases are active over a broad pH (5-9) and temperature $\left(35-105^{\circ} \mathrm{C}\right)$ ranges, they are worldwide center of attraction for researchers. Many microorganisms like fungi, yeast, bacteria, and actinomycetes produce this enzyme; however, enzyme from fungal and bacterial sources has dominated applications in industrial sectors [7]. However, bacterial amylases are preferred as they grow rapidly, need less space, can be easily maintained, and are accessible for genetic manipulations. The important amylase producing bacteria are species of Bacillus, Pseudomonas, Halomonas, Arthrobacter, and Serratia. Among the bacterial sources, Bacillus subtilis, B. stearothermophilus, B. amyloliquefaciens, B. licheniformis, B. acidocaldarius, Bifidobacterium bifidum, and $B$. macerans $[3,8,9]$ play an important role in production of amylase. Several species of Bacillus are industrially 
employed to produce thermostable amylase as they grow easily under extreme $\mathrm{pH}$ and temperature conditions.

The application of an amylase in industrial reactions depends on its unique characteristics, such as its action pattern, substrate specificity, major reaction products, optimal temperature, and optimal $\mathrm{pH}[10]$. They are mainly employed for starch liquefaction to reduce their viscosity, production of maltose, oligosaccharide mixtures, high fructose syrup, and maltotetraose syrup. In detergents production, they are applied to improve cleaning effect and are also used for starch desizing in textile industry [11]. Generally, production of this enzyme has been carried out by submerged fermentation [8] because of the ease of sterilization and process control that is easier to engineer in these systems. The purpose of this study is to isolate a novel thermotolerant amylase producing bacteria in the presence of organic solvent. Simultaneous optimization and characterization of different parameters were also performed in this study.

\section{Materials and Methods}

2.1. Isolation, Screening, and Identification of Thermotolerant Amylase Producing Bacteria. The soil samples were collected aseptically from different sites of University campus to isolate amylase producing bacteria. One g soil was suspended in $9.0 \mathrm{~mL}$ sterile distilled water, agitated for a min and $0.1 \mathrm{~mL}$ suspension was spread over nutrient starch agar plates $(\mathrm{pH}$ 7.0) containing $2.0 \%$ starch; $0.5 \%$ peptone; $0.3 \%$ beef extract; $0.5 \% \mathrm{NaCl} ; 2 \%$ agar. The inoculated plates were overlaid with $7.0 \mathrm{~mL}$ of cyclohexane and incubated at $55^{\circ} \mathrm{C}$ till sufficient growth appeared. After sufficient growth incubated plates were overlaid with Gram's iodine reagent $\left(0.01 \mathrm{M} \mathrm{I}_{2}\right.$-KI solutions). If a strain was amylolytic, then it started hydrolyzing the starch present in the surrounding and in the zone degradation there was no blue color formation. Selection was done as per colonies with and without clear and transparent zone as amylase producing (Amy+) and amylase nonproducing (Amy-) strain, respectively. Bacterial colonies showing clear zones were selected, streaked twice on starch agar plates for purification, and maintained as pure culture over nutrient agar slants $\left(\mathrm{pH} 7,4^{\circ} \mathrm{C}\right)$. The isolate having maximum clearance zone was selected for further studies. The selected bacterial isolate RG-01 was identified by morphological and biochemical characterization as per Bergey's Manual of Systematic Bacteriology [12]. The identity of RG-01 was authenticated from the Institute of Microbial Technology (IMTECH), Chandigarh, India, based on the phenotypic (16S rDNA) and biochemical tests.

2.2. Inoculum Preparation. Mother culture was prepared by inoculating one full loop of $24 \mathrm{~h}$ grown culture on starch agar plate in $50 \mathrm{~mL}$ starch broth and incubated at $55^{\circ} \mathrm{C}$ for $24 \mathrm{~h}$ to achieve active exponential phase containing $3.2 \times 10^{8} \mathrm{cfu} / \mathrm{mL}$. Suitable amount $(0.5 \%, \mathrm{v} / \mathrm{v})$ of this cell suspension was used to inoculate the test flasks.

2.3. Crude Enzyme Preparation. To obtain crude enzyme, $24 \mathrm{~h}$ old cultures were transferred to microcentrifuge tubes and centrifuged at $10000 \mathrm{rpm}$ for $10 \mathrm{~min}$. Cells were discarded and resultant supernatant was used as the crude enzyme for various enzyme assays (activity).

2.4. $\alpha$-Amylase Assay (Activity). The activity of $\alpha$-amylase was assayed by measuring the reducing sugar released by reaction on starch $[13,14]$. Amylase assay was done by using a reaction mixture consisting of $500 \mu \mathrm{L}$ of substrate solution (1.0\% soluble starch in $1.0 \mathrm{M}$ sodium phosphate buffer $\mathrm{pH}$ 7.0), $100 \mu \mathrm{L}$ of the enzyme solution, and $1 \mathrm{~mL}$ volume make up by adding $400 \mu \mathrm{L}$ distilled water. The reaction mixture was incubated for $10 \mathrm{~min}$ at $55^{\circ} \mathrm{C}$. Reaction was stopped by adding $1 \mathrm{~mL}$ of alkaline copper tartrate solution. The reaction mixture was heated to $100^{\circ} \mathrm{C}$ for $10 \mathrm{~min}$ and cooled and then added to arsenomolybdate solution for color stabilization. Optical density of each sample with reaction mixture was taken at $620 \mathrm{~nm}$ in a spectrophotometer (Shimadzu, Japan). One unit of $\alpha$-amylase activity was defined as the amount of enzyme that liberates $1.0 \mu \mathrm{g}$ of glucose (reducing end groups) per $\mathrm{min} / \mathrm{mL}$ in $1.0 \mathrm{M}$ sodium phosphate buffer $(\mathrm{pH} 7.0)$ with $1.0 \%(\mathrm{w} / \mathrm{v})$ soluble starch as substrate at $55^{\circ} \mathrm{C}$.

2.5. Culture Conditions and Medium Selection. The selected isolate RG-01 was grown in nutrient starch and modified (in our laboratory) nutrient starch broth. The modified nutrient starch broth contained 2.0\% starch; 0.5\% peptone; $0.3 \%$ beef extract; $0.5 \% \mathrm{NaCl} ; 0.05 \% \mathrm{MgSO}_{4}$. To study the growth behavior and amylase production, $1.0 \mathrm{~mL}$ of mother culture having $0.8 \mathrm{OD}\left(\mathrm{A}_{620} ; 1 \mathrm{~cm}\right.$ cuvette $)$ containing $3.2 \times$ $10^{8} \mathrm{cfu} / \mathrm{mL}$ was inoculated in $99 \mathrm{~mL}$ of broth ( $\mathrm{pH} 7.0$; adjusted with $1 \mathrm{~N} \mathrm{NaOH}$ ) in Erlenmeyer flasks and incubated at $55 \pm$ $1^{\circ} \mathrm{C}$ on incubator shaker $(100 \mathrm{rpm})$ for $24 \mathrm{~h}$. At $4 \mathrm{~h}$ interval, bacterial growth was assessed by turbidity measurement at $620 \mathrm{~nm}$. Each sample was centrifuged at $10,000 \mathrm{rpm}\left(4^{\circ} \mathrm{C}\right)$ for $10 \mathrm{~min}$ and cell-free supernatant was assayed for amylase activity.

2.6. Optimization of Physicochemical and Nutritional Parameters for Amylase Production. The various process parameters influencing amylase production were optimized individually and independently of the others. Therefore, the optimized conditions were subsequently used in all the experiments in sequential order. For optimization, the basal medium was inoculated and incubated at different temperatures, viz, 35, $40,45,50,55,60,65,70$, and $75^{\circ} \mathrm{C}$ under the standard assay conditions. The samples were withdrawn at every $4 \mathrm{~h}$ interval up to $48 \mathrm{~h}$ to study the effect of incubation periods. The influence of $\mathrm{pH}$ on the enzyme activity was determined by measuring the enzyme activity at varying $\mathrm{pH}$ values ranging from 5.0 to 12.0 at $55^{\circ} \mathrm{C}$ using different suitable buffers at concentration of $100 \mathrm{mM}$ citrate buffer $(\mathrm{pH} 5.0-6.0,1 \mathrm{M})$, phosphate buffer (6.0-7.5), Tris- $\mathrm{HCl}$ buffer ( $\mathrm{pH} 8.0-9.0)$, and glycine- $\mathrm{NaOH}$ (9.5-11.0) under standard assay conditions. The growth medium was supplemented with different carbon sources, viz, starch (soluble), potato starch, wheat bran, rice bran, glucose, fructose, lactose, maltose, and sucrose (at the level of $2 \%, \mathrm{w} / \mathrm{v}$ ). Different nitrogen sources (beef extract, 


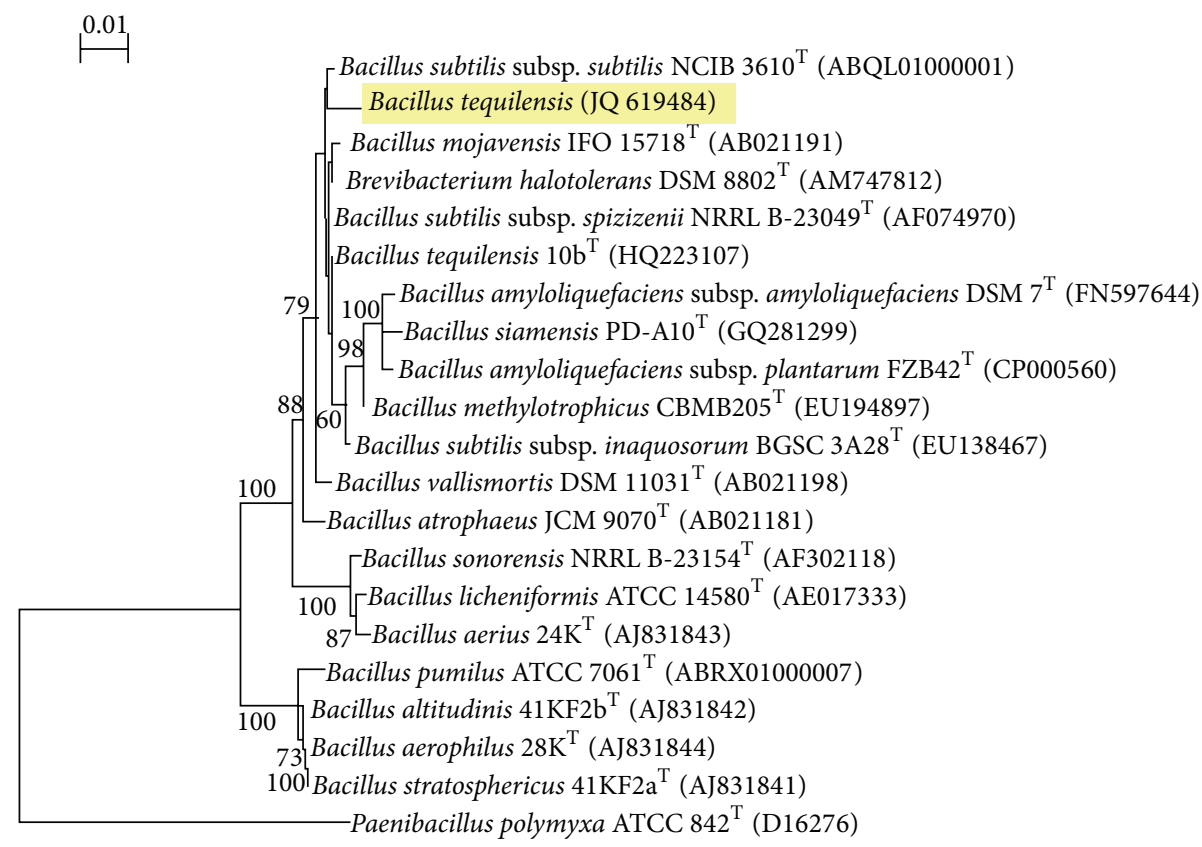

FIgURE 1: Phylogenetic tree showing relation between strain RG-01 and other Bacillus strains.

yeast extract, peptone, urea, ammonium sulphate, ammonium chloride, and ammonium hydrogen phosphate $0.5 \%$ w/v) were also used for enzyme production. Thereafter, optimized carbon and nitrogen sources were further optimized at different concentrations.

2.7. Effect of Organic Solvents on Amylase Stability. Cellfree supernatant having maximum amylase activity was filtered with nitrocellulose membrane (pore size $0.22 \mu \mathrm{m}$ ) and incubated with $30 \%$ (v/v) of different organic solvents, viz, ndodecane, n-decane, isooctane, n-octane, xylene, n-hexane, n-butanol, cyclohexane, n-heptane, benzene, toluene, ethanol, methanol, and propanol for 7 days in screw crapped tubes at $55^{\circ} \mathrm{C}$ and $120 \mathrm{rpm}$. The residual amylase activity was estimated against the control, in which solvent was not present.

2.8. Effect of Metal Ions on Enzyme Activity and Stability. The effect of various metal ions $(25 \mathrm{mM})$ on enzyme activity was investigated using $\mathrm{FeSO}_{4}, \mathrm{CaCl}_{2}, \mathrm{KCl}, \mathrm{NaCl}, \mathrm{MgSO}_{4}, \mathrm{MnCl}_{2}$, $\mathrm{ZnSO}_{4}, \mathrm{CuSO}_{4}, \mathrm{HgCl}_{2}$, and $\mathrm{NiCl}_{2}$. The enzyme was incubated with different metals at $55^{\circ} \mathrm{C}$ for $1 \mathrm{~h}$ to study metal ion stability and assayed under standard assay conditions. The effect of different concentrations ( $5 \mathrm{mM}$ to $45 \mathrm{mM}$ ) of $\mathrm{CaCl}_{2}, \mathrm{NaCl}$, and $\mathrm{MgSO}_{4}$ on amylase activity was also evaluated under standard assay conditions.

2.9. Effect of Surfactants on Enzyme Stability. The effect of various surfactants $(1.0 \%)$ on enzyme activity was investigated using Triton-X-100, Tween-40, Tween-60, Tween-80, and SDS. The amylase sample was incubated with surfactants for $1 \mathrm{~h}$ at $55^{\circ} \mathrm{C}$ and then the residual activity (\%) was tested under standard assay conditions.
2.10. SDS-PAGE Analysis. The enzyme supernatant with maximum enzyme activity along with marker was electrophoresed by sodium dodecyl sulphate-poly acrylamide gel electrophoresis in a $12.5 \%$ polyacrylamide gel according to the method of Laemmli [15]. Approximate molecular weight of the amylase was estimated by SDS-PAGE against the molecular mass markers, i.e., lysozyme $(14.3 \mathrm{kDa}), \beta$ lactoglobulin $(20 \mathrm{kDa})$, carbonic anhydrase $(29 \mathrm{kDa})$, ovalbu$\min (43 \mathrm{kDa})$, bovine serum albumin $(66 \mathrm{kDa})$, and phosphorylase B $(97.4 \mathrm{kDa})$ (Sigma-Aldrich Pvt Ltd., USA) run with the samples.

2.11. Statistical Analysis. All experiments were carried out in triplicates and the results are presented as the mean of three independent observations. Standard deviation for each experimental result was calculated using Microsoft Excel.

\section{Results and Discussion}

3.1. Isolation, Screening, and Identification of Thermotolerant Organic Solvent-Resistant Amylase Producing Bacterial Cultures. Ten (10) bacterial isolates producing variable amylolytic zones on starch agar plates which stained with iodine solution were isolated from the soil samples in the presence of cyclohexane. The zones of clearance by isolates reflect their extent of amylolytic activity. Those having clearance zone greater than $>1.5 \mathrm{~cm}$ were considered as significant. Among 10 bacterial isolates, 5 exhibited good amylase activity which was reassessed by loading their culture broth in the wells on starch agar plates which stained with iodine solution ( $\mathrm{pH}$ 7.0). The culture broth of good amylase producers cleared more than $>1.5 \mathrm{~cm}$ zone within $3-4 \mathrm{~h}$ of incubation at $55 \pm 1^{\circ} \mathrm{C}$, thereby indicating an extra-cellular nature of the amylase. The 
TABLE 1: Morphological, physiological, and biochemical characteristics of the selected RG-01 isolate.

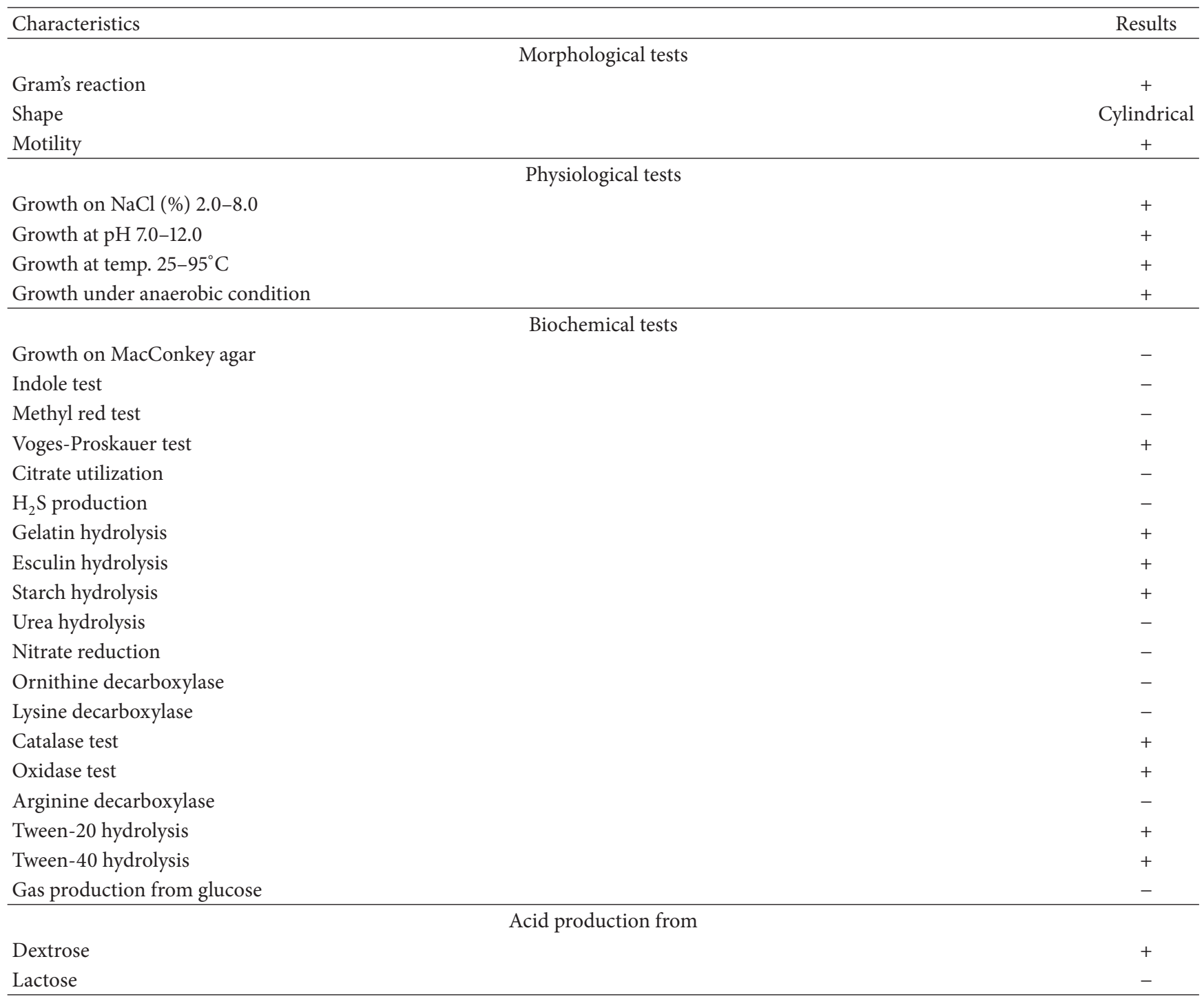

(+): positive; (-): negative.

isolate RG-01, showing maximum clearance zone diameter, was selected for further studies.

The efficient strain RG-01 was rod-shaped, Gram-positive, aerobe and facultative, motile, with positive VogesProskauer, catalase and oxidase test. It grew over a wide range of $\mathrm{pH}(5-12)$, temperature $\left(15^{\circ}-85^{\circ} \mathrm{C}\right)$, and $\mathrm{NaCl}$ concentration $(0.0-16 \%)$, and it was able to hydrolyze gelatin, esculin, starch, Tween-20, and Tween-40 and produce acid from glucose. The strain was halotolerant as it grew in the presence of $0.0-12 \% \mathrm{NaCl}$ but did not require salt for its physiological activities (Table 1). On account of morphological and biochemical characteristics, it was identified as Bacillus sp. by MTCC MTECH, Chandigarh, India. Analysis of 16S rDNA sequence (1444 bp) revealed its $99.3 \%$ homology with Bacillus tequilensis strains and was designated as Bacillus tequilensis RG-09. The 1444 bp $16 \mathrm{~S}$ rDNA sequence was submitted to GenBank (JQ: 619484). The strain RG-09 was in the same cluster of phylogenetic tree (Figure 1) with different strains of Bacillus tequilensis. However, the $16 \mathrm{~S}$ rDNA sequence analysis indicates that it is a different and novel strain of Bacillus tequilensis. The $16 \mathrm{~S}$ rDNA is the most widely accepted gene employed for bacterial classification and identification. Gupta et al. [16] emphasized that the use of molecular markers like $16 \mathrm{~S}$ rDNA as species-specific identification tool has been provided with a truly "microscopic" sensitivity down to single-cell detection.

3.2. Culture Conditions and Medium Selection. The RG-01 strain exhibited typical sigmoidal growth behavior in both culture media. In nutrient starch broth, stationary phase commenced at $24 \mathrm{~h}$, while, in modified nutrient starch broth, the onset of stationary phase was at $20 \mathrm{~h}$ onward after a steep log phase. In both media, the stationary phase of bacterial growth witnessed maximum amylase production. However, 


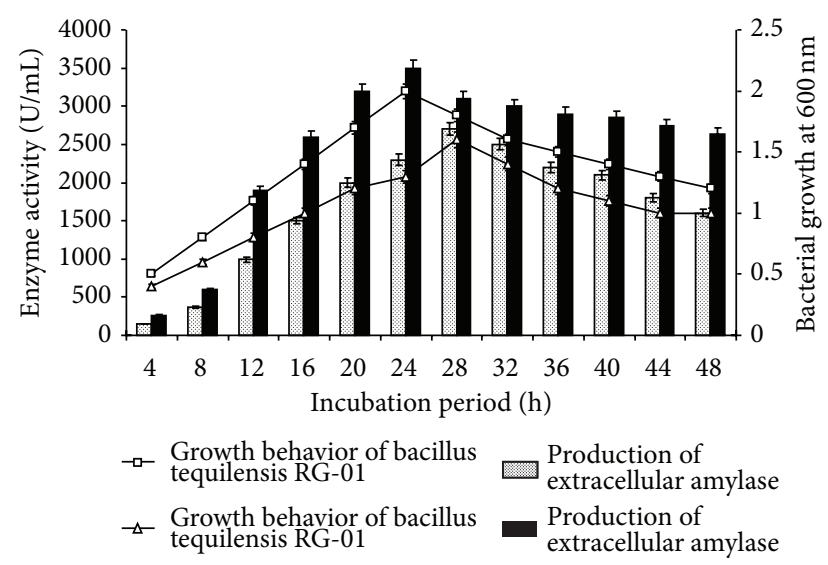

FIGURE 2: Growth behavior of Bacillus tequilensis RG-01 and production of extracellular amylase, respectively, in starch nutrient media and modified starch nutrient media at initial $\mathrm{pH} 7.0$ and $55^{\circ} \mathrm{C}$ and $120 \mathrm{rpm}$ during $48 \mathrm{~h}$ growth.

the amylase production was the maximum $(3500 \mathrm{U} / \mathrm{mL})$ in modified nutrient starch medium at $20 \mathrm{~h}$, while it was $2700 \mathrm{U} / \mathrm{mL}$ at $24 \mathrm{~h}$ in nutrient starch medium (Figure 2). Hence, modified nutrient starch medium was selected for further studies on amylase production.

3.3. Effect of Different Temperatures. Effect of different temperatures, viz, $35^{\circ} \mathrm{C}$ to $75^{\circ} \mathrm{C}$, was evaluated for amylase production, activity, and stability by Bacillus tequilensis RG01 at different physicochemical and nutritional levels. Bacillus tequilensis RG-01 showed higher amylase production, activity, and stability $(4000 \mathrm{U} / \mathrm{mL}, 100 \%$, and $119 \%)$ at $55^{\circ} \mathrm{C}$. This culture also sustains its activity and stability $(81 \%$ and $96.3 \%)$ at $65^{\circ} \mathrm{C}$. Further increase in temperature could not affect the amylase production by Bacillus tequilensis RG-01 (Figure 3). Similarly, Anto et al. [17] also reported that $\alpha$ amylase production by B. subtilis at $70^{\circ} \mathrm{C}$ is $90 \%$ activity and was observed compared to the optimum enzyme activity at $55^{\circ} \mathrm{C}$ for liquefaction of starch. For $\alpha$-amylase produced by a Bacillus isolate AS-1, 88, 85, and $44 \%$ of activity have been reported at 60,70 , and $80^{\circ} \mathrm{C}$, respectively [18].

3.4. Effect of Different $p H$. Among the physical parameters, the $\mathrm{pH}$ of the growth medium plays an important role by inducing morphological change in the organism and in enzyme secretion $[19,20]$. Different $\mathrm{pH}, v i z, 5.0$ to 12.0 in the medium, was tested for amylase production, activity, and stability by Bacillus tequilensis RG-01 at their optimal temperature and incubation period. Bacillus tequilensis RG01 showed $5200 \mathrm{U} / \mathrm{mL}$ enzyme productions, $100 \%$ activity, and $127 \%$ stability at $\mathrm{pH} 7.0$ (Figure 4 ). Most of the Bacillus strains used commercially for the production of bacterial $\alpha$ amylases have an optimum pH between 6.0 and 7.0 for growth and enzyme production $[4,18]$. Strain RG-01 showed $86 \%$ activity and $91 \%$ stability at $\mathrm{pH} 9.0$ (Figure 4). Haq et al. [21] reported $\mathrm{pH} 7.5-8.0$ to be the best for the production of alpha amylase by Bacillus subtilis. Further increase and decrease in the medium $\mathrm{pH}$ reduced the enzyme production, activity,

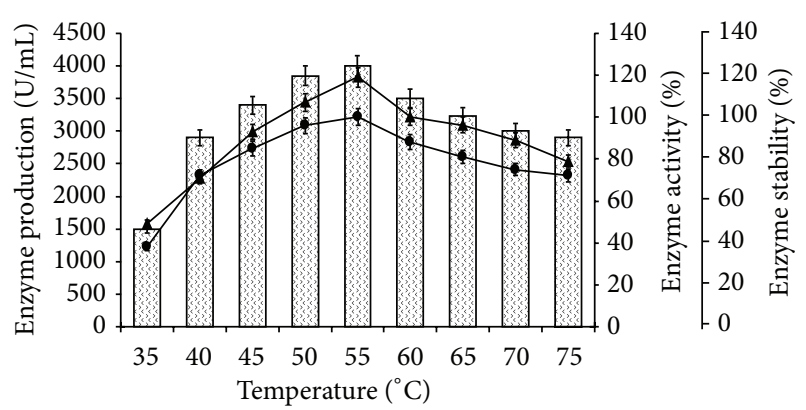

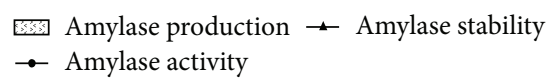

FIGURE 3: Effect of temperature on amylase production, activity, and stability. The flasks were inoculated with culture in the medium and were incubated at different temperature $\left(35-75^{\circ} \mathrm{C}\right)$ for $24 \mathrm{~h}$ at $\mathrm{pH}$ 7.0. For enzyme activity, reaction mixture was incubated at different temperatures $\left(35-75^{\circ} \mathrm{C}\right)$ and for stability enzyme was preincubated at respective temperatures for $1 \mathrm{~h}$ and reaction was conducted as standard assay method. Error bars presented mean values of \pm standard deviation of triplicates of three independent experiments.

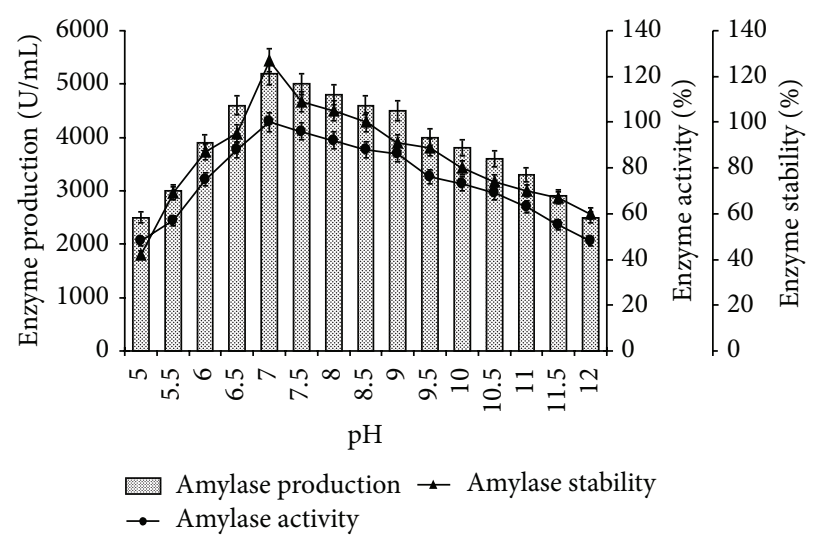

FIGURE 4: Effect of $\mathrm{pH}$ on amylase production, activity, and stability. The flasks were inoculated with culture and were incubated at different $\mathrm{pH}(5-12)$ for $24 \mathrm{~h}$ at $55^{\circ} \mathrm{C}$. For enzyme activity, the reaction was assayed at respective $\mathrm{pH}$ and for stability enzyme was preincubated with buffers $(100 \mathrm{mM}$, in ratio $1: 1)$ of different $\mathrm{pH}$ (512) at $55^{\circ} \mathrm{C}$ for $1 \mathrm{~h}$ and assayed by standard assay method. Error bars presented mean values of \pm standard deviation of triplicates of three independent experiments.

and stability (Figure 4). The $\mathrm{pH}$ change observed during the growth of the organism also affects product stability in the medium. Results show that enzyme production was generally active and stable from pH 5.0 to 10.0, which indicates excellent buffering property. The $\mathrm{pH}$ values also serve as a valuable indicator of the initiation and end of enzyme synthesis [22].

3.5. Effect of Different Incubation Periods. Just after optimization of temperature for amylase production, in the liquid medium, incubation period was optimized for enzyme production and stability. The results clearly indicated that 


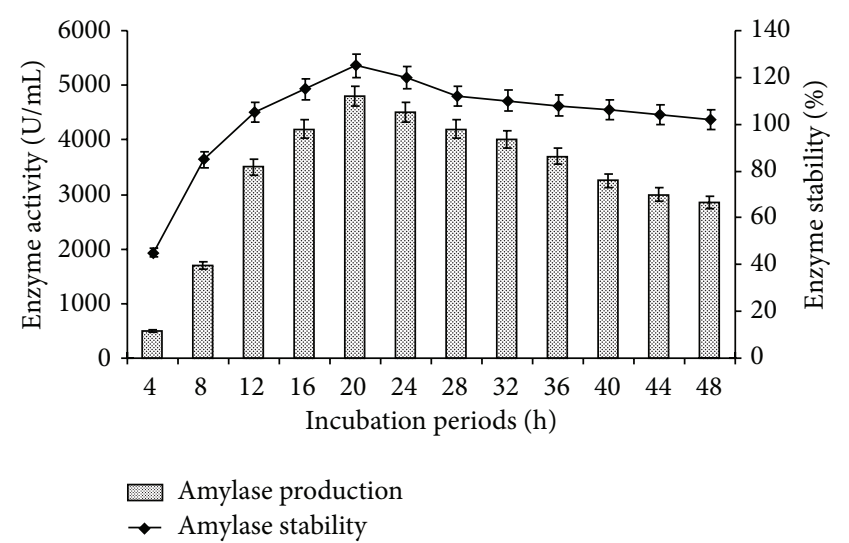

FIGURE 5: Effect of incubation periods on amylase production and stability. The flasks were inoculated with culture and were incubated at different incubation periods $\left(4-48 \mathrm{~h}\right.$ ) at initial $\mathrm{pH} 7.0,55^{\circ} \mathrm{C}$. For enzyme activity, the reaction was assayed at respective incubation periods and for stability enzyme was preincubated for $4-48 \mathrm{~h}$ at $55^{\circ} \mathrm{C}$ for $1 \mathrm{~h}$ and assayed by standard assay method. Error bars presented mean values of \pm standard deviation of triplicates of three independent experiments.

Bacillus tequilensis RG-01 showed $4800 \mathrm{U} / \mathrm{mL}$ enzyme activity with $125 \%$ stability in $20 \mathrm{~h}$ of incubation (Figure 5). Further increase in the incubation period did not increase the enzyme production, but the stability of enzyme is $100 \%$ in $72 \mathrm{~h}$ (data not shown). In contrast to our results, Özdemir et al. [23] reported that $\alpha$-amylase production by B. subtilis was maximum $(2902 \mathrm{U} / \mathrm{mg})$ in $72 \mathrm{~h}$, after which a gradual decrease was observed. It may be due to denaturation or decomposition of $\alpha$-amylase owing to interaction with other components in the medium, as it is reported elsewhere [24]. Incubation time depends on the characteristics of the culture, on growth rate, and enzyme production [25]. Moreover, the reaction for maximum enzyme production at $72 \mathrm{~h}$ could be due to the fact that the microorganism was in its exponential phase. At later stage, when nutrients are depleted, it reaches its stationary phase and can start to produce secondary metabolites, thus resulting in a lower yield of enzyme [26]. Thus, our strain producing $\alpha$-amylase within $20 \mathrm{~h}$ of incubation is better than that reported by the other workers mentioned above.

3.6. Effect of Different Carbon Sources. Various carbon sources, viz, starch, wheat bran, rice bran, rice husk, potato starch, glucose, fructose, lactose, maltose, and sucrose at a concentration of $2.0 \%(\mathrm{w} / \mathrm{v})$ were individually tested in the basal medium at their optimal temperature, incubation period, and $\mathrm{pH}$ to observe the effect on enzyme production by Bacillus tequilensis RG-01. Out of these carbon sources, starch (soluble) was found to be the best for amylase production $(5200 \mathrm{U} / \mathrm{mL})$ by the strain RG-01 followed by potato starch within $24 \mathrm{~h}$ (Figure 6). Similarly, Gangadharan et al. [27] reported that Bacillus amyloliquefaciens gave the highest enzyme yield $(62470 \mathrm{U} / \mathrm{g})$ with soluble starch, followed by maltose $(58499 \mathrm{U} / \mathrm{g})$.

Bacillus tequilensis RG-01 also showed maximum enzyme production $(4800,4550$, and $4010 \mathrm{U} / \mathrm{mL})$ in the presence of

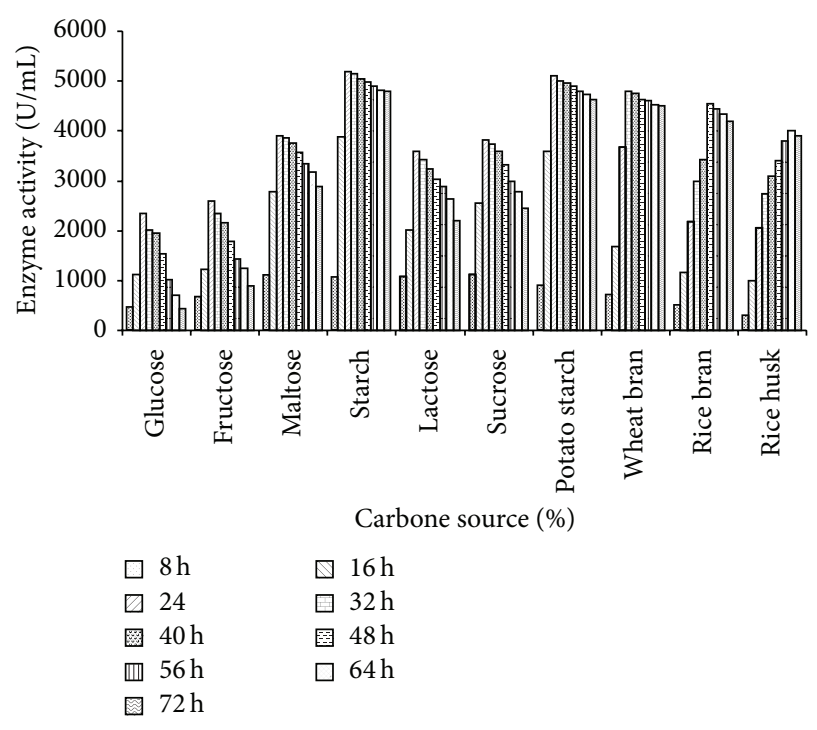

FIGURE 6: Effect of different carbon sources and incubation periods on amylase production. Test flasks contained different carbon sources in the medium at a level of $2 \%(\mathrm{w} / \mathrm{v})$. The flasks were inoculated with culture and incubated at $55^{\circ} \mathrm{C}$ for $4-48 \mathrm{~h}$ at $\mathrm{pH} 7.0$. Error bars presented are mean values of \pm standard deviation of triplicates of three independent experiments.

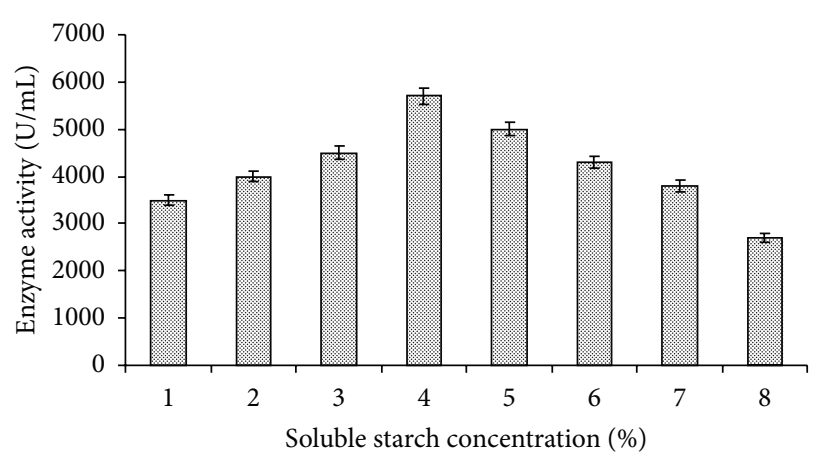

FIGURE 7: Effect of different concentration of soluble starch on amylase production. Test flasks contained different concentrations of starch $(1.0-8.0, \mathrm{w} / \mathrm{v})$ in the medium. The flasks were inoculated with culture and incubated at $55^{\circ} \mathrm{C}$ for $24 \mathrm{~h}$ at $\mathrm{pH}$ 7.0. Error bars presented are mean values of \pm standard deviation of triplicates of three independent experiments.

wheat bran, rice bran, and rice husk within 32,48 , and $64 \mathrm{~h}$ of incubation (Figure 6). Anto et al. [17] also reported that $B$. cereus using wheat bran showed highest production $(122 \pm 5 \mathrm{U} / \mathrm{g})$. Bacillus tequilensis RG-01 showed considerable enzyme production with maltose, lactose, and sucrose within $24 \mathrm{~h}$ of incubation (Figure 6). Amylase production in the presence of maltose, lactose, and sucrose was also reported by some other workers [28]. Bacillus tequilensis RG-01 showed minimum enzyme production in the presence of glucose and fructose (Figure 6). Some workers reported that supplementation of glucose caused a negative effect on amylase production $[23,29]$. Glucose was found to repress the enzyme yield, which may be due to feedback inhibition caused by 
the presence of reducing sugars. Easily metabolizable carbohydrates may result in better growth of the bacteria along with reduction in the enzyme formation [30,31].

In another set of the experiment, different concentrations of starch $(1.0,2.0,3.0,4.0,5.0,6.0,7.0$, and $8.0 \%, \mathrm{w} / \mathrm{v})$ in the medium were tested for amylase production at the same growth conditions at which carbon sources were evaluated. Bacillus tequilensis RG-01 showed $5700 \mathrm{U} / \mathrm{mL}$ amylase production at $4 \%$ starch (soluble) concentration; above this concentration enzyme production was slightly decreased (Figure 7).

3.7. Effect of Different Nitrogen Sources. Inorganic and organic nitrogen, viz, peptone, beef extract, yeast extract, urea, ammonium sulphate, ammonium chloride, and ammonium hydrogen phosphate, at the rate of $0.5 \%(\mathrm{w} / \mathrm{v})$ were used in the basal medium for amylase production by Bacillus tequilensis RG-01 (Figure 8). The enzyme production by the isolate was almost similar in beef extract and peptone amended medium $(6000 \mathrm{U} / \mathrm{mL})$ followed by yeast extract and ammonium sulphate. Similarly, Thippeswamy et al. [32] reported that the addition of peptone increases amylase production by Bacillus sp. Bacillus tequilensis RG-01 also showed better amylase production in the presence of ammonium chloride and ammonium hydrogen phosphate. Narang and Satyanarayana [28] also reported that ammonium chloride and ammonium hydrogen phosphate favoured growth and enzyme secretion by bacterial strains. Other nitrogen source, like urea, showed inhibitory effect on amylase production of Bacillus tequilensis RG-01. Ramachandran et al. [26] have already reported that supplementation of urea at $1 \%$ concentration resulted in a decrease in amylase production.

Different concentrations of peptone $(0.1,0.2,0.3,0.4,0.5$, and $0.6 \%, \mathrm{w} / \mathrm{v})$ in the medium were also tested for amylase production at the same growth condition at which nitrogen sources were evaluated. Bacteria showed higher enzyme production $(6200 \mathrm{U} / \mathrm{mL})$ at $0.3 \%$ peptone concentration, further increase in concentration, reduced enzyme production (Figure 9).

\subsection{Effect of Organic Solvents on Amylase Stability. In another} approach, the effect of various organic solvents $(30 \%, \mathrm{v} / \mathrm{v})$ on amylase stability was also investigated for 7 days, and the results are depicted in Table 2. The amylase of Bacillus tequilensis RG-01 is extraordinarily stable in the presence of all organic solvents under study. It was observed that except for benzene, methanol, and ethanol, presence of other solvents enhanced the amylase activity. After incubation with $\mathrm{n}$-dodecane, isooctane, $\mathrm{n}$-decane, xylene, toluene, $\mathrm{n}$-hexane, n-butanol, and cyclohexane, the amylase activity increased to $232,160,168.8,120,170.2,133,144$, and $120 \%$, respectively. The presence of benzene, methanol, and ethanol marginally reduced the amylase with residual activities of 72, 93.3, and $78.3 \%$, respectively (Table 2). An organic solvent stable alkaline protease has been reported from P. aeruginosa PseA by Gupta and Khare [33]. After 10 days of incubation with organic solvents $(25 \%, \mathrm{v} / \mathrm{v})$, the residual protease activities were $112,75,98,92,97,94,75,90,96,102$, and $104 \%$ in

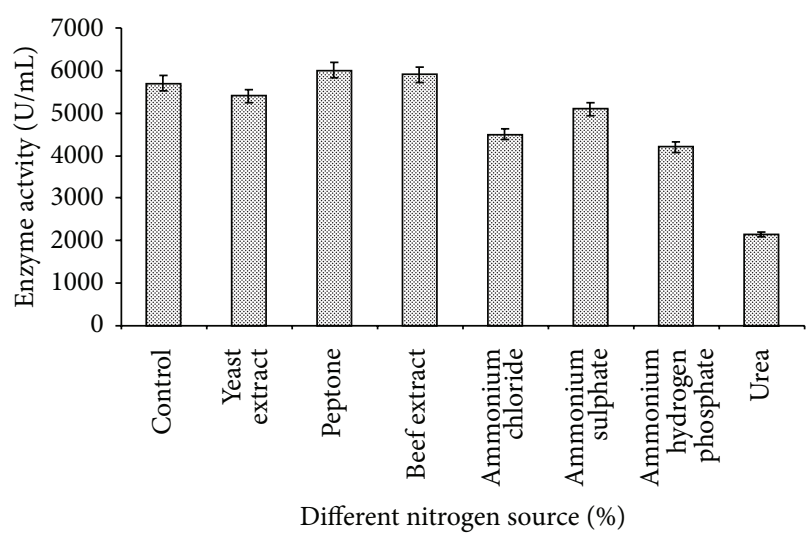

Figure 8: Effect of different nitrogen sources on amylase production. The control flask does not contain any nitrogen sources. Test flasks contained different nitrogen sources in the medium at a level of $0.5 \%(\mathrm{w} / \mathrm{v})$. The flasks were inoculated with culture and incubated at $55^{\circ} \mathrm{C}$ for $24 \mathrm{~h}$ at $\mathrm{pH} 7.0$ with $4.0 \%$ starch. Error bars presented are mean values of \pm standard deviation of triplicates of three independent experiments.

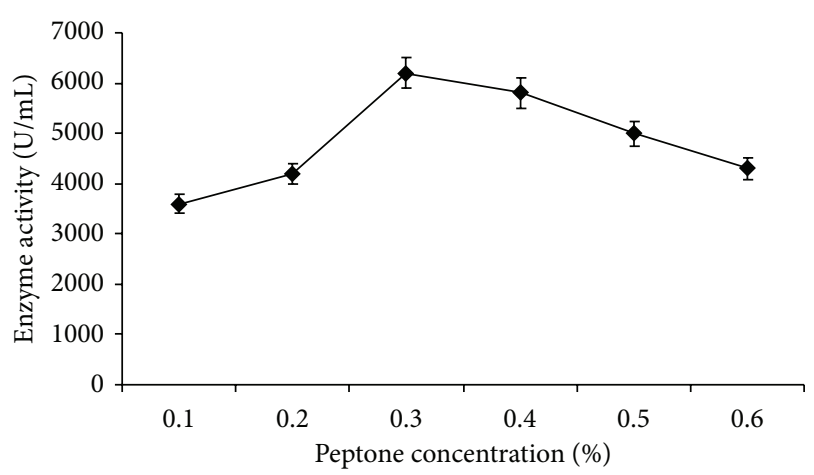

FIgURE 9: Effect of different concentration of peptone on amylase production. Test flasks contained different concentration of peptone $(0.1-0.6 \%, \mathrm{w} / \mathrm{v})$ in the medium. The flasks were inoculated with culture and incubated at $55^{\circ} \mathrm{C}$ for $24 \mathrm{~h}$ at $\mathrm{pH}$ 7.0. Error bars presented are mean values of \pm standard deviation of triplicates of three independent experiments.

the presence of ethanol, 1-butanol, benzene, toluene, xylene, cyclohexane, hexane, heptane, isooctane, n-decane, and ndodecane, respectively. Abusham et al. [34] also reported that protease of B. subtilis strain showed enhanced activity in the presence of organic solvents $(25 \%, \mathrm{v} / \mathrm{v})$. It is therefore evident from our study that amylase of Bacillus tequilensis RG-01 is remarkably stable in the presence of broad range hydrophilic as well as hydrophobic organic solvents employed in this study.

3.9. Effect of Different Metal Salts. For the study of the effect of metal ions, viz, $\mathrm{NaCl}, \mathrm{CaCl}_{2}, \mathrm{MgSO}_{4}, \mathrm{HgCl}_{2}, \mathrm{FeSO}_{4}, \mathrm{NiCl}_{2}$, $\mathrm{CuSO}_{4}, \mathrm{CoCl}_{2}$, and $\mathrm{ZnCl}_{2}$ at a concentration of $25 \mathrm{mM}$ were individually tested in the basal medium at their optimal temperature, incubation period, and $\mathrm{pH}$ to observe the effect on enzyme production and stability by Bacillus tequilensis 
TABLE 2: Stability of crude amylase in presence of various organic solvents.

\begin{tabular}{|c|c|c|c|c|c|c|c|c|c|}
\hline \multirow{2}{*}{ Organic solvents (30\%) } & \multirow{2}{*}{$\log P$} & \multicolumn{8}{|c|}{ Residual activity (\%) } \\
\hline & & $1 \mathrm{~h}$ & $24 \mathrm{~h}$ & $48 \mathrm{~h}$ & $72 \mathrm{~h}$ & $96 \mathrm{~h}$ & $120 \mathrm{~h}$ & $144 \mathrm{~h}$ & $168 \mathrm{~h}$ \\
\hline Methanol & -0.76 & 101.9 & 130.5 & 133.2 & 125.3 & 120.6 & 113.4 & 106.3 & 93.3 \\
\hline Isopropanol & -0.28 & 90.2 & 100.3 & 96.3 & 90.4 & 89.5 & 86.4 & 80.3 & 75.4 \\
\hline Ethanol & -0.24 & 97 & 105.6 & 103.5 & 100.6 & 96.5 & 90.4 & 81.2 & 78.3 \\
\hline Benzene & 2.13 & 99 & 110 & 95 & 90 & 86 & 81 & 78 & 72 \\
\hline Cyclohexane & 3.3 & 87 & 105 & 120 & 102 & 99 & 91 & 80 & 75 \\
\hline Acetone & -0.23 & 101.5 & 105.4 & 103.9 & 100.8 & 95 & 90 & 85 & 80 \\
\hline Butanol & -0.80 & 112.7 & 144.3 & 128.2 & 115.4 & 107.6 & 100.3 & 100 & 95 \\
\hline Toluene & 2.5 & 115.9 & 170.2 & 140.1 & 127.1 & 120.8 & 112.9 & 105.5 & 100.3 \\
\hline Isooctane & 2.9 & 120 & 160.1 & 125.5 & 120.5 & 113.4 & 110.3 & 105.7 & 99.2 \\
\hline Xylene & 3.1 & 89 & 107 & 120 & 110 & 106 & 100 & 94 & 91 \\
\hline Hexane & 3.6 & 114 & 133 & 124 & 118 & 113 & 104 & 100 & 100 \\
\hline n-Decane & 5.6 & 125.3 & 151.3 & 168.8 & 148.3 & 126.2 & 101.7 & 100 & 99.0 \\
\hline n-Dodecane & 6.0 & 131.8 & 160.2 & 232.3 & 158.1 & 149.9 & 120.2 & 108.0 & 100.0 \\
\hline
\end{tabular}

Enzyme was preincubated with different organic solvents at a concentration of $30 \%(\mathrm{v} / \mathrm{v})$ at $55^{\circ} \mathrm{C}$ for different time periods and assayed as standard assay method. The enzyme activity without incubation with organic solvent was taken as $100 \%$. Mean standard deviation for all values is $< \pm 5.0 \%$.

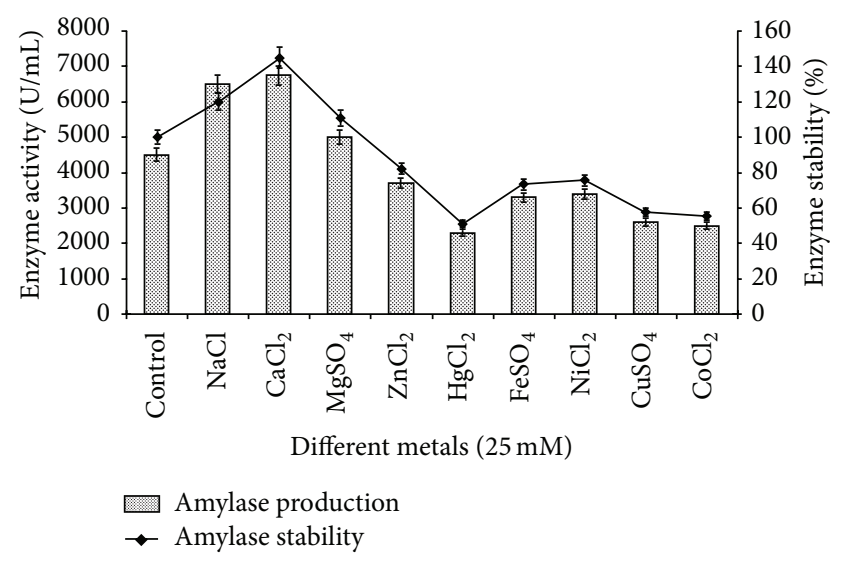

FIGURE 10: Effect of different metal ions on amylase production and stability. The control flask does not contain any metal ions. Test flasks contained different metal ions in the medium at a level of $25 \mathrm{mM}$. The flasks were inoculated with culture and were incubated at initial $\mathrm{pH} 7.0,55^{\circ} \mathrm{C}$ for $24 \mathrm{~h}$. For enzyme activity, the reaction was assayed and for stability enzyme was preincubated with different metal ions $(25 \mathrm{mM})$ at $55^{\circ} \mathrm{C}$ for $1 \mathrm{~h}$ and assayed by standard assay method. Error bars presented mean values of \pm standard deviation of triplicates of three independent experiments.

RG-01. Out of these metal ions, sodium and calcium ions were found to be the best for amylase production (6500 and $6750 \mathrm{U} / \mathrm{mL}$ ) and stability (120 and 145\%). While amylase production and stability of Bacillus tequilensis RG-01 were slightly reduced in the presence of $\mathrm{Fe}^{2+}, \mathrm{Mg}^{2+}, \mathrm{Cu}^{2+}, \mathrm{Ni}^{2-}$, $\mathrm{Co}^{2+}$, and $\mathrm{Zn}^{2+}$. Bacillus tequilensis $\mathrm{RG}-01$ also tolerates $25 \mathrm{mM} \mathrm{HgCl}_{2}$, a novel finding of this strain (Figure 10). Amylolytic enzymes are metalloenzymes with up to six $\mathrm{Ca}^{2+}$ atoms at the active site whose catalytic activity can be affected by mono- and divalent metals [35]. $\mathrm{Ca}^{2+}$ enhanced the activity of $\alpha$-amylase from C. perfringens [36], B. subtilis [37],

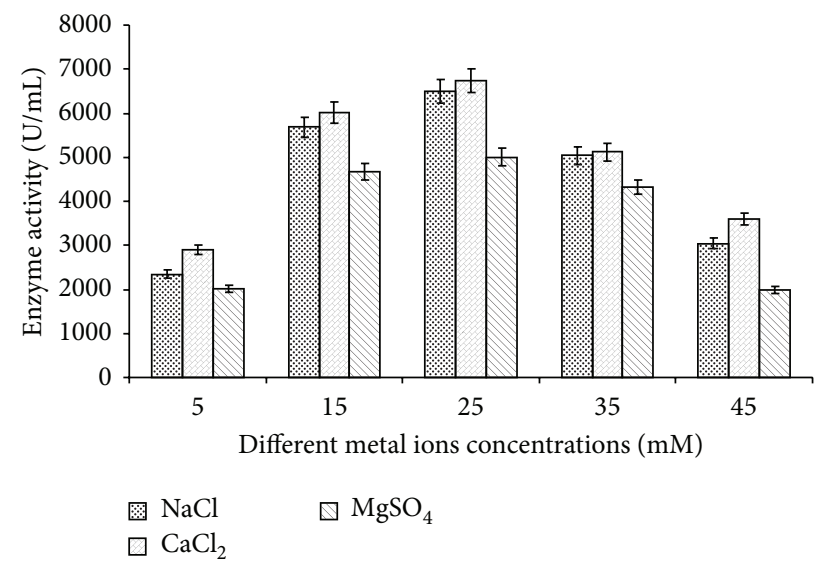

FIGURE 11: Effect of different concentration of metal ions $(\mathrm{NaCl}$, $\mathrm{CaCl}_{2}$, and $\mathrm{MgSO}_{4}$ ) on amylase production. Test flasks contained different concentrations ( $5 \mathrm{mM}$ to $45 \mathrm{mM}$ ) of metal ions $(\mathrm{NaCl}$, $\mathrm{CaCl}_{2}$, and $\left.\mathrm{MgSO}_{4}\right)$ in the medium. The flasks were inoculated with culture and were incubated at initial $\mathrm{pH} 7.0,55^{\circ} \mathrm{C}$ for $24 \mathrm{~h}$. For enzyme activity, the reaction was assayed by standard assay method. Error bars presented mean values of \pm standard deviation of triplicates of three independent experiments.

and Acremonium sporosulcatum [38]. The inhibition of $B$. subtilis JS-2004 $\alpha$-amylase by $\mathrm{Co}^{2+}, \mathrm{Cu}^{2+}$, and $\mathrm{Ba}^{2+}$ ions could be due to competition between the exogenous cations and the protein associated cations, resulting in decreased metalloenzymes activity [39]. Hernandez et al. [40] reported that amylase activity was strongly inhibited by $\mathrm{Cu}^{2+}, \mathrm{Hg}^{2+}$, and $\mathrm{Zn}^{2+}$.

Different concentrations of $\mathrm{NaCl}, \mathrm{CaCl}_{2}$, and $\mathrm{MgSO}_{4}$ (5, $10,15,25,35$, and $45 \mathrm{mM}$ ) in the medium were also tested for amylase production at the same growth condition at which metal ion sources were evaluated. Bacteria showed same pattern of amylase production with $\mathrm{NaCl}, \mathrm{CaCl}_{2}$, and 


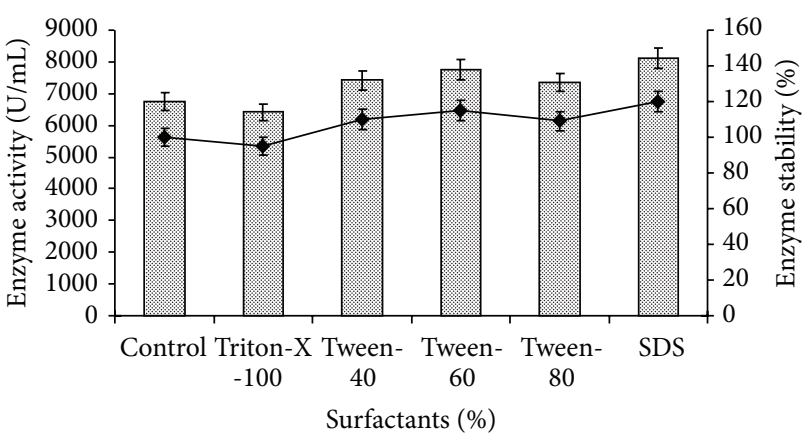

FIGURE 12: Effect of different surfactants on amylase production and stability. The control flask does not contain any surfactant. Test flasks contained different surfactant in the medium at a level of $1.0 \%(\mathrm{w} / \mathrm{v})$. The flasks were inoculated with culture and were incubated at initial $\mathrm{pH} 7.0,55^{\circ} \mathrm{C}$ for $24 \mathrm{~h}$. For enzyme activity, the reaction was assayed and for stability enzyme was preincubated with different surfactants $(1.0 \%)$ at $55^{\circ} \mathrm{C}$ for $1 \mathrm{~h}$ and assayed by standard assay method. Error bars presented mean values of \pm standard deviation of triplicates of three independent experiments.

$\mathrm{MgSO}_{4}$ at $25 \mathrm{Mm}$ concentration but maximum amylase production was reported from the $\mathrm{CaCl}_{2}$. By further increase and decrease in the concentration of all three metal ions, enzyme production was reduced (Figure 11).

3.10. Effect of Surfactants on Amylase Activity. None of the surfactants tested had a pronounced inhibitory effect on enzyme activities. Only Triton-X-100 showed a moderate inhibitory effect (5\%) on amylase activity of Bacillus tequilensis RG-01 (Figure 12). On the other hand, the addition of SDS, Tween-40, Tween-60, and Tween-80 (1\%) was found to stimulate activity by $20,10,15$, and $9 \%$, respectively. The stimulatory effect of surfactants on amylase activity is controversial. Oberoi et al. [41] also reported that the activity of amylase of Bacillus sp. was stimulated in the presence of Tween-80 (1\%). Arnesen et al. [42] reported that amylase activity of Thermomyces lanuginosus was slightly inhibited by Triton X-100. A stimulatory effect of SDS (6\%) on amylase activity and stability in Bacillus sp. strain TS-23 was documented by Lo et al. [43]. From the previous reports and the present study, it was evident that the same surfactant could have different effects on the activity of the same enzyme in the same microorganism or on the activity of different enzymes in the same microorganism.

3.11. SDS-PAGE Analysis of Amylase Enzyme. The purity of the enzyme was confirmed by the presence of a single band on SDS-PAGE and its molecular weight was approximately $67 \mathrm{kDa}$ (Figure 13), which was similar to Bacillus subtilis amylase $(67 \mathrm{kDa})$ [44] but different from Bacillus sp. YX-1 amylase $(56 \mathrm{kDa})[45]$.

\section{Conclusion}

A thermotolerant solvent stable amylase is produced by a novel isolate Bacillus tequilensis RG-01. The organism appears

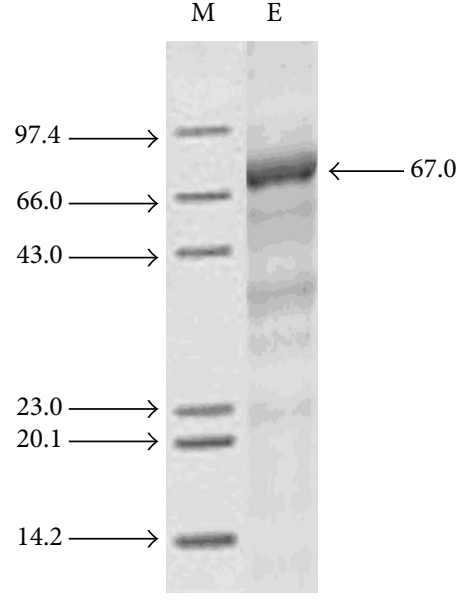

FIGURE 13: Photographic representation of the SDS-PAGE of amylase of Bacillus tequilensis. Lane 1: marker proteins; lane 2: enzyme supernatant (amylase). Molecular weights were presented in the form of $\mathrm{kDa}$.

to have greater potential for enhanced enzyme production through optimization of nutritional and physical parameters. Tolerance against temperature, $\mathrm{pH}$, organic solvents, metal ions, and surfactants facilitates its use for various processes under stressed conditions. Owing to its (Bacillus tequilensis RG-01) thermotolerant nature, its amylase may have potential uses in industries such as detergent, food, pharmaceutical, leather, and agriculture, as well as molecular biology techniques.

\section{Conflict of Interests}

The authors declare that there is no conflict of interests regarding the publication of this paper.

\section{Acknowledgment}

Financial assistance by Council of Science and Technology, UP, is greatly acknowledged by Rajeeva Gaur and Soni Tiwari.

\section{References}

[1] M. J. van der Maarel, B. van der Veen, J. C. Uitdehaag, H. Leemhuis, and L. Dijkhuizen, "Properties and applications of starch-converting enzymes of the $\alpha$-amylase family," Journal of Biotechnology, vol. 94, no. 2, pp. 137-155, 2002.

[2] A. Burhan, U. Nisa, C. Gökhan, C. Ömer, A. Ashabil, and G. Osman, "Enzymatic properties of a novel thermostable, thermophilic, alkaline and chelator resistant amylase from an alkaliphilic Bacillus sp. isolate ANT-6," Process Biochemistry, vol. 38, no. 10, pp. 1397-1403, 2003.

[3] P. V. Aiyer, "Amylases and their applications," African Journal of Biotechnology, vol. 4, no. 13, pp. 1525-1529, 2005.

[4] R. Vidyalakshmi, R. Paranthaman, and J. Indhumathi, "Amylase production on submerged fermentation by Bacillus sp." World Journal of Chemistry, vol. 4, no. 1, pp. 89-91, 2009. 
[5] A. Maton, H. Jean, W. Charles et al., Human Biology and Health, Prentice Hall, Englewood Cliffs, NJ, USA, 1993.

[6] A. O. Ajayi and O. E. Fagade, "Utilization of corn starch as substrate for $\beta$-amylase by Bacillus sp.," African Journal of Biomedical Research, vol. 6, no. 1, pp. 37-42, 2003.

[7] K. Kathiresan and S. Manivannan, " $\alpha$-Amylase production by Penicillium fellutanum isolated from mangrove rhizosphere soil," African Journal of Biotechnology, vol. 5, no. 10, pp. 829-832, 2006.

[8] H. A. El Enshasy, "Bioprocess development for the production of $\alpha$-amylase by Bacillus amyloliquefaciens in batch and fedbatch cultures," Research Journal of Microbiology, vol. 2, no. 7, pp. 560-568, 2007.

[9] Z. Konsoula and M. Liakopoulou-Kyriakides, “Thermostable $\alpha$ amylase production by Bacillus subtilis entrapped in calcium alginate gel capsules," Enzyme and Microbial Technology, vol. 39, no. 4, pp. 690-696, 2006.

[10] J. Yun, S. Kang, S. Park et al., "Characterization of a novel amylolytic enzyme encoded by a gene from a soil-derived metagenomic library," Applied and Environmental Microbiology, vol. 70, no. 12, pp. 7229-7235, 2004.

[11] W. H. Chengyi, M. Ming, and R. Jiang, "Studies on the properties of alpha-amylase produced by Bacillus pumilus 289 (PBX96)," Acta Microbiologica Sinica, vol. 32, no. 6, pp. 400404, 1999.

[12] R. N. Creig and G. J. Holt, Bergey's Manual of Systematic Bacteriology, Williams \& Wilkins, London, UK, 1984.

[13] N. Nelson, "A photometric adaptation of the Somogyi method for the determination of glucose," The Journal of Biological Chemistry, vol. 153, pp. 375-380, 1944.

[14] M. Somogyi, "Notes on sugar determination," The Journal of Biological Chemistry, vol. 195, no. 1, pp. 19-23, 1952.

[15] U. K. Laemmli, "Cleavage of structural proteins during the assembly of the head of bacteriophage T4," Nature, vol. 227, no. 5259, pp. 680-685, 1970.

[16] R. Gupta, Q. Beg, and P. Lorenz, "Bacterial alkaline proteases: molecular approaches and industrial applications," Applied Microbiology and Biotechnology, vol. 59, no. 1, pp. 15-32, 2002.

[17] H. Anto, U. Trivedi, and K. Patel, "Alpha amylase production by Bacillus cereus MTCC 1305 using solid-state fermentation," Food Technology and Biotechnology, vol. 44, no. 2, pp. 241-245, 2006.

[18] S. K. Soni, A. Kaur, and J. K. Gupta, "A solid state fermentation based bacterial $\alpha$-amylase and fungal glucoamylase system and its suitability for the hydrolysis of wheat starch," Process Biochemistry, vol. 39, no. 2, pp. 185-192, 2003.

[19] R. Gupta, P. Gigras, H. Mohapatra, V. K. Goswami, and B. Chauhan, "Microbial $\alpha$-amylases: a biotechnological perspective," Process Biochemistry, vol. 38, no. 11, pp. 1599-1616, 2003.

[20] H. Pedersen and J. Nielsen, "The influence of nitrogen sources on the $\alpha$-amylase productivity of Aspergillus oryzae in continuous cultures," Applied Microbiology and Biotechnology, vol. 53, no. 3, pp. 278-281, 2000.

[21] I. U. Haq, H. Ashraf, J. Iqbal, and M. A. Qadeer, "Biosynthesis of $\alpha$-amylase by chemically treated mutant of Bacillus subtilis," Online Journal of Biological Sciences, vol. 2, no. 2, pp. 73-75, 2002.

[22] J. Friedrich, A. Cimerman, and W. Steiner, "Submerged production of pectolytic enzymes by Aspergillus niger: effect of different aeration/agitation regimes," Applied Microbiology and Biotechnology, vol. 31, no. 5, pp. 490-494, 1989.

[23] S. Özdemir, K. Güven, Z. Baysal, and F. Uyar, "Screening of various organic substrates and the development of a suitable lowcost eermentation medium for the production of $\alpha$-amylase by Bacillus subtilis," Food Technology and Biotechnology, vol. 47, no. 4, pp. 364-369, 2009.

[24] M. V. Ramesh and B. K. Lonsane, "A novel bacterial thermostable alpha-amylase system produced under solid state fermentation," Biotechnology Letters, vol. 9, no. 7, pp. 501-504, 1987.

[25] Z. Baysal, F. Uyar, and Ç. Aytekin, "Solid state fermentation for production of $\alpha$-amylase by a thermotolerant Bacillus subtilis from hot-spring water," Process Biochemistry, vol. 38, no. 12, pp. 1665-1668, 2003.

[26] S. Ramachandran, A. K. Patel, K. M. Nampoothiri et al., "Coconut oil cake-a potential raw material for the production of $\alpha$-amylase," Bioresource Technology, vol. 93, no. 2, pp. 169-174, 2004.

[27] D. Gangadharan, S. Sivaramakrishnan, K. M. Nampoothiri, and A. Pandey, "Solid culturing of Bacillus amyloliquefaciens for alpha amylase production," Food Technology and Biotechnology, vol. 44, no. 2, pp. 269-274, 2006.

[28] S. Narang and T. Satyanarayana, "Thermostable $\alpha$-amylase production by an extreme thermophile Bacillus thermooleovorans," Letters in Applied Microbiology, vol. 32, no. 1, pp. 31-35, 2001.

[29] V. H. Mulimani and G. N. P. Ramalingam, " $\alpha$-Amylase production by solid state fermentation: a new practical approach to biotechnology courses," Biochemical Education, vol. 28, no. 3, pp. 161-163, 2000.

[30] M. Y. Yoon, Y. J. Yoo, and T. W. Cadman, "Phosphate effects in the fermentation of $\alpha$-amylase by Bacillus amyloliquefaciens," Biotechnology Letters, vol. 11, no. 1, pp. 57-60, 1989.

[31] R. Rama and S. K. Srivastav, "Effect of various carbon substrates on $\alpha$-amylase production from Bacillus species," Journal of Microbiology and Biotechnology, vol. 10, pp. 76-82, 1995.

[32] S. Thippeswamy, K. Girigowda, and V. H. Mulimani, "Isolation and identification of $\alpha$-amylase producing Bacillus sp. from dhal industry waste," Indian Journal of Biochemistry and Biophysics, vol. 43, no. 5, pp. 295-298, 2006.

[33] A. Gupta and S. K. Khare, "Enhanced production and characterization of a solvent stable protease from solvent tolerant Pseudomonas aeruginosa PseA," Enzyme and Microbial Technology, vol. 42, no. 1, pp. 11-16, 2007.

[34] R. A. Abusham, R. N. Z. R. A. Rahman, A. Salleh, and M. Basri, "Optimization of physical factors affecting the production of thermo-stable organic solvent-tolerant protease from a newly isolated halo tolerant Bacillus subtilis strain Rand," Microbial Cell Factories, vol. 8, article 20, 2009.

[35] K. T. Normurodova, S. K. Nurmatov, B. K. Alimova, O. M. Pulatova, Z. R. Akhmedova, and A. A. Makhsumkhanov, "Isolation and characteristics of highly active $\alpha$-amylase from Bacillus subtilis-150," Chemistry of Natural Compounds, vol. 43, no. 4, pp. 454-457, 2007.

[36] N. J. Shih and R. G. Labbe, "Purification and characterization of an extracellular $\alpha$-amylase from Clostridium perfringens type A," Applied and Environmental Microbiology, vol. 61, no. 5, pp. 1776-1779, 1995.

[37] M. Asgher, M. J. Asad, S. U. Rahman, and R. L. Legge, "A thermostable $\alpha$-amylase from a moderately thermophilic Bacillus subtilis strain for starch processing," Journal of Food Engineering, vol. 79, no. 3, pp. 950-955, 2007. 
[38] V. K. Valaparla, "Purification and properties of a thermostable $\alpha$-amylase by Acremonium Sporosulcatum," International Journal of Biotechnology and Biochemistry, vol. 6, pp. 25-34, 2010.

[39] E. Lévêque, Š. Janeček, B. Haye, and A. Belarbi, "Thermophilic archaeal amylolytic enzymes," Enzyme and Microbial Technology, vol. 26, no. 1, pp. 3-14, 2000.

[40] M. S. Hernandez, M. R. Rodriguez, N. P. Guerra, and R. P. Roses, "Amylase production by Aspergillus niger in submerged cultivation on two wastes from food industries," Journal of Food Engineering, vol. 73, no. 1, pp. 93-100, 2006.

[41] R. Oberoi, Q. K. Beg, S. Puri, R. K. Saxena, and R. Gupta, "Characterization and wash performance analysis of an SDSstable alkaline protease from a Bacillus sp," World Journal of Microbiology and Biotechnology, vol. 17, no. 5, pp. 493-497, 2001.

[42] S. Arnesen, S. H. Eriksen, J. Ø. Olsen, and B. Jensen, "Increased production of $\alpha$-amylase from Thermomyces lanuginosus by the addition of Tween 80," Enzyme and Microbial Technology, vol. 23, no. 3-4, pp. 249-252, 1998.

[43] H.-F. Lo, L.-L. Lin, H.-L. Chen, W.-H. Hsu, and C.-T. Chang, "Enzymic properties of a SDS-resistant Bacillus sp. TS-23 $\alpha$ amylase produced by recombinant Escherichia coli," Process Biochemistry, vol. 36, no. 8-9, pp. 743-750, 2001.

[44] T. Yandri Suhartati and S. Hadi, "Purification and characterization of extracellular $\alpha$-amilase enzyme from locale bacteria isolate Bacillus subtilis ITBCCB148," European Journal of Scientific Research, vol. 39, pp. 64-74, 2010.

[45] X. D. Liu and Y. Xu, "A novel raw starch digesting $\alpha$-amylase from a newly isolated Bacillus sp. YX-1: purification and characterization," Bioresource Technology, vol. 99, no. 10, pp. 4315-4320, 2008. 

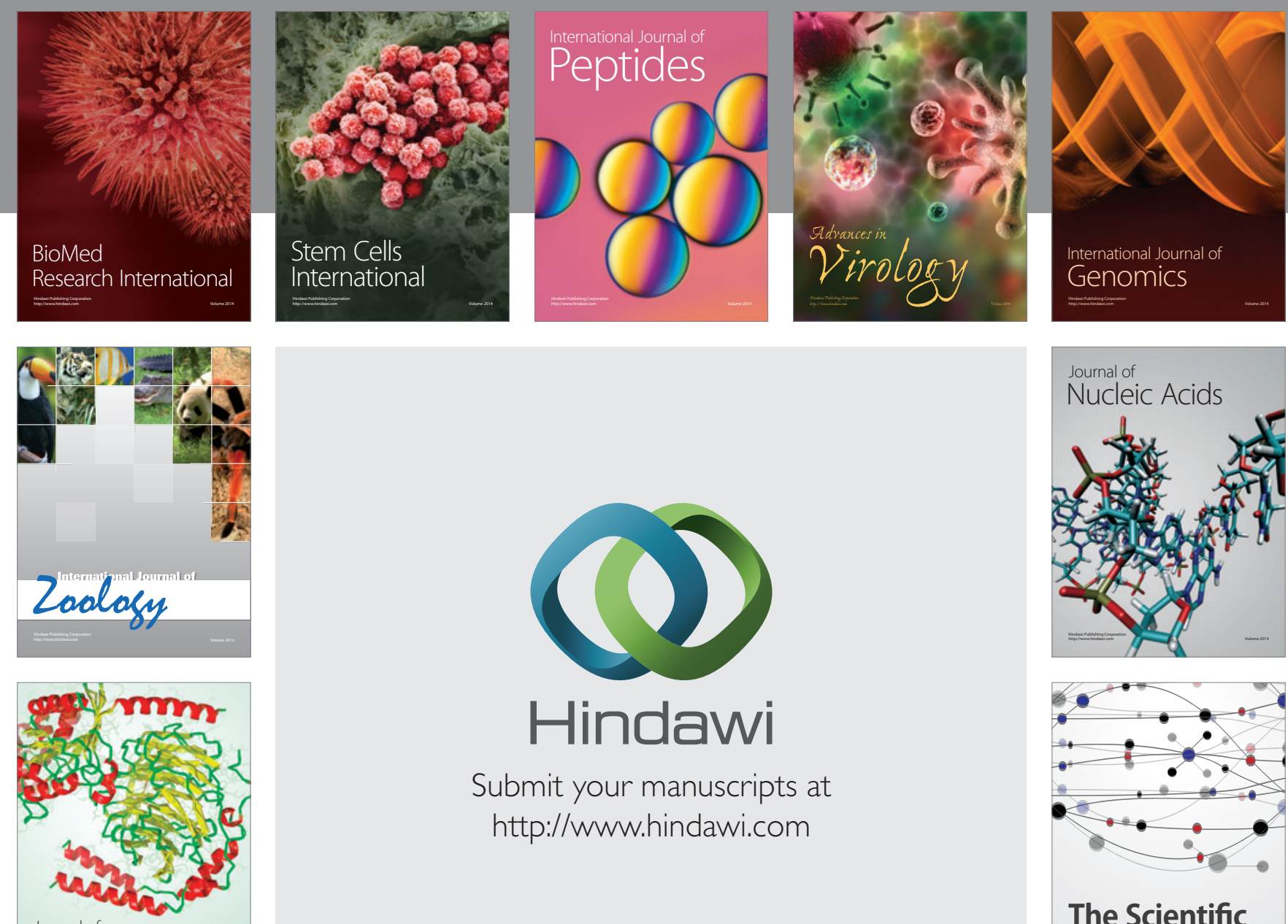

Submit your manuscripts at

http://www.hindawi.com

Journal of
Signal Transduction
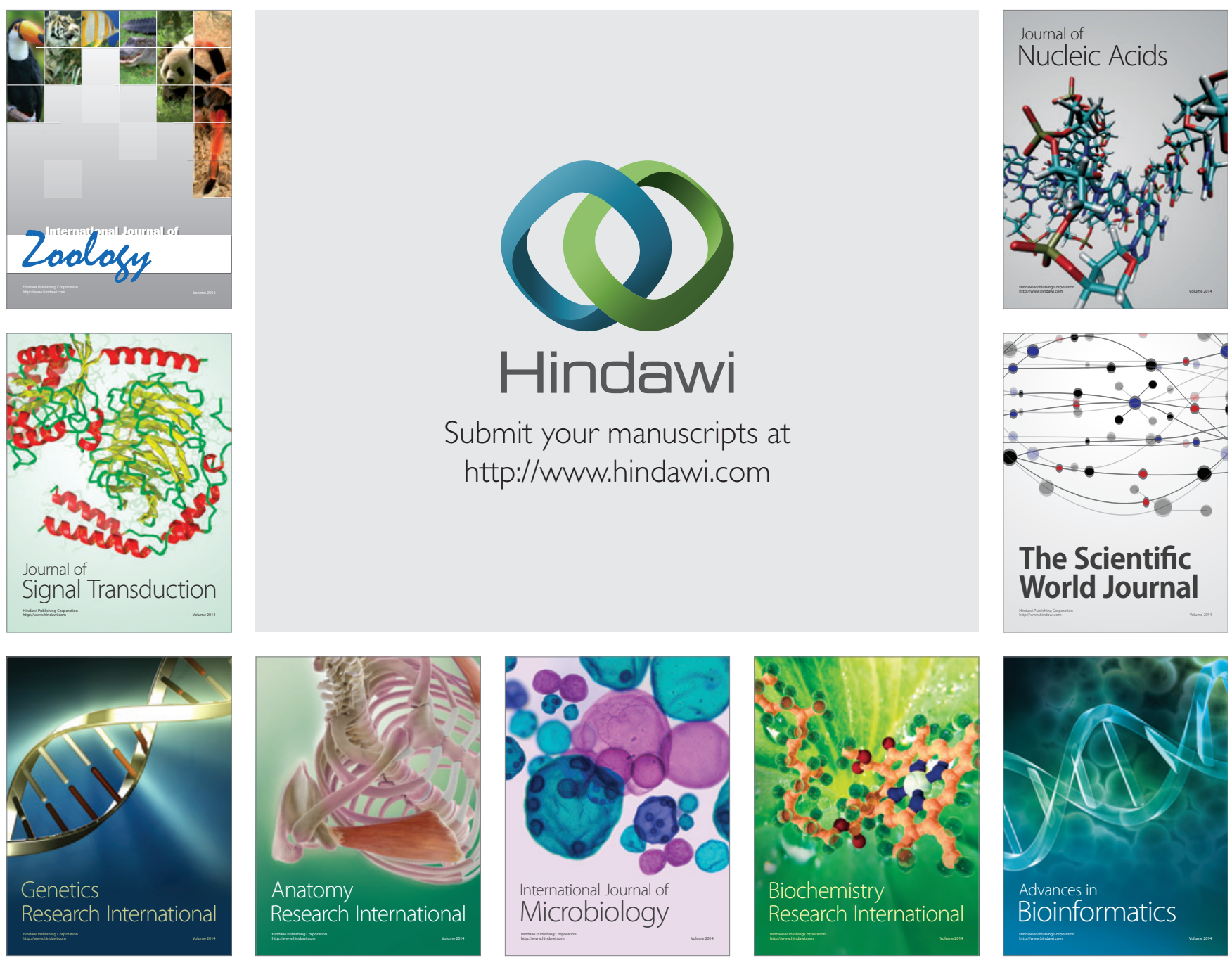

The Scientific World Journal
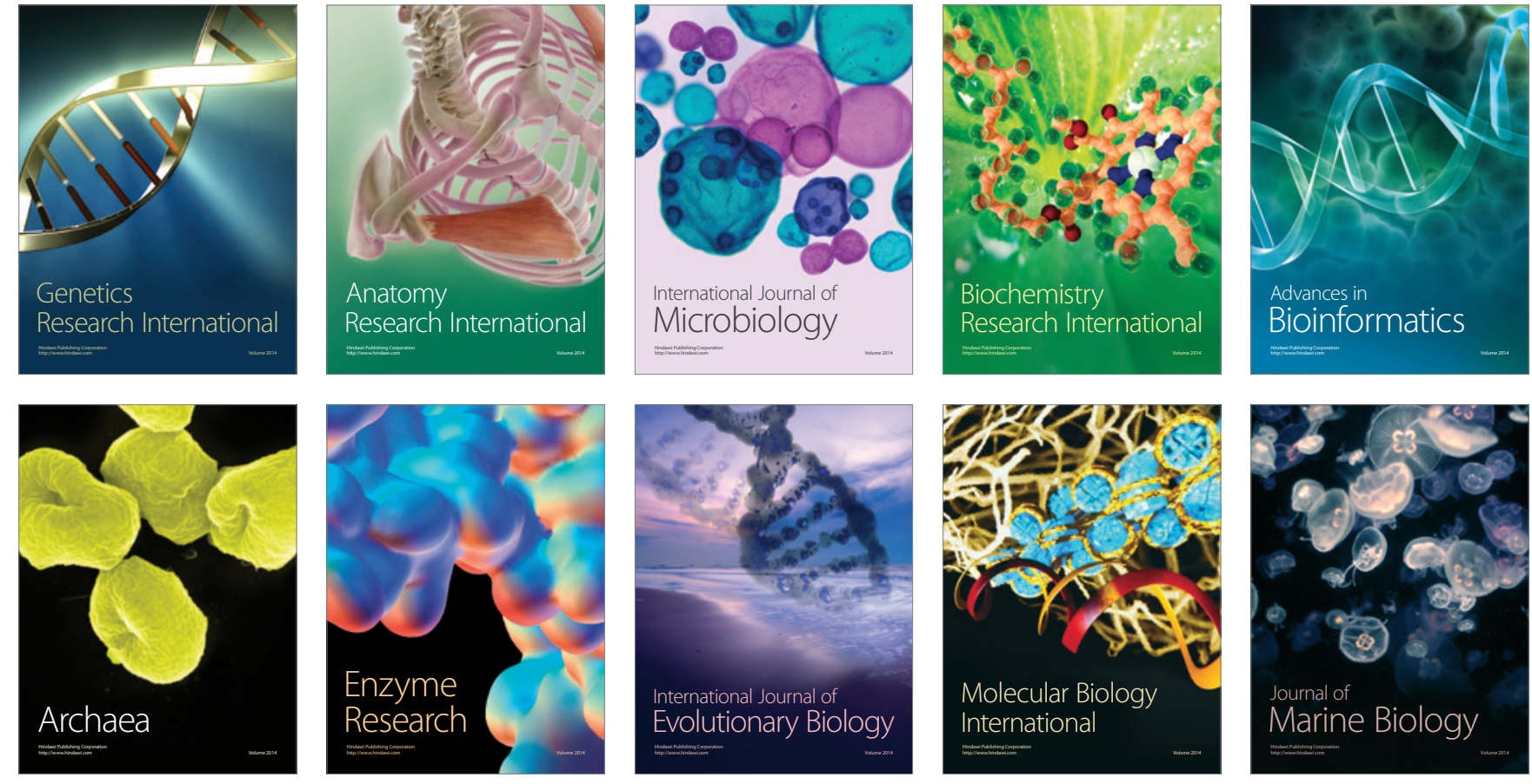